\title{
MAXIMIZING THE BENEFITS OF JAPANESE TYPE COMBINE FOR WHEAT REAPING
}

\section{El-Beba. A. M; *Yusuf Y. Ramadan*; and Mokhtar C. Ahmed*}

\section{ABSTRACT}

An investigation was carried out to determine and estimate the factors and conditions which make Japanese type combine available in use for wheat reaping. The study included removing threshing and winnowing parts and heightening the pick-up shaft to 5, 10, 15 and $20 \mathrm{~cm}$ above the original position with: Fixing repel arms to forward wheat stems to fall aside or fixing a metal mat for transferring wheat stems to fall freely to the ground behind the reaper, as well as installation a back load base. Tests were carried out under travel speed of 1.25, 1.8; 2.4; 3.0 and 3.6 $\mathrm{km} / \mathrm{h}$ and nails (claws) speed of 25; 33; 42 and $55 \mathrm{rev} / \mathrm{min}$ as well as the fall height of 40; 50; 65 and $80 \mathrm{~cm}$ for reaped stems. The percentage of grain loss (\%), field capacity fed/h, cutting efficiency\%, fuel consumption liters $/ h$ and total costs have been estimated. Results showed that increasing travel speed from 1.25 to $3 \mathrm{~km} / \mathrm{h}$ increased losses by $6 \%$ and increased field efficiency by about 18-20\%. Increased claws speed from 25 to $42 \mathrm{rev} / \mathrm{min}$ increased losses by 3\%. Heightening the pick-up shaft from the original position zero to $20 \mathrm{~cm}$ reduced losses by $60 \%$ while increased efficiency by $6 \%$. Assembling back pile base at $50-80 \mathrm{~cm}$ increased the total losses by 53.6\%. Power requirements decreased by 5.8 $\%$ by using repel arms comparing to using a mat. The total cost for reaping one feddan decreased by $75 \%$ comparing to manual reaping costs for the same area.

\section{INTRODUCTION}

$\mathrm{M}$ any wheat harvesters are used widely in Egypt such as CASE, NEWHOLAND, CHEUCURIA and CLAAS harvesters, reapers, mowers, and modified mower mounted on tractors or self-propelled. However, each type had advantages and disadvantages while using for harvesting wheat.

\footnotetext{
*Agricultural Engineering Research Institute, Agric. Res. Center, Dokki-Giza
} 
The most effecting factor is the tibn characteristics as all mentioned harvesters failed to produce the proper tenderizing tibn desired by Egyptian farmers. Labor problem faces the Egyptian farmers especially at planting and harvesting periods. Japanese combines which are available and usual using under Egyptian conditions widely in Egypt for complete rice harvesting. Applying combine at reaping of wheat crop after harvesting rice can be estimated as an economic study specially, the labor are rare and expensive at these periods of year. This application could be beneficial for former combines which cannot efficiently operate at rice season or before re-maintenance for preparing to the principal rice season harvesting. Kepner et al. (1972) stated that the common way of the cutting forces was by means of two opposed shearing elements. In the way of applying the cutting forces by single cutting elements, the material being cut may transmit the force required to oppose a single cutting element. An impact cutter having a single high speed cutting element relies primarily upon inertia of the material being cut to furnish the opposing required force for shear. El-Sahar (1988) indicated that the cuttings force is greatly affected by the diameter of the plant stem. For three types of plant stem of cotton, wheat and lawn, $625 \mathrm{~N}$ force was needed to cut of $9 \mathrm{~mm}$ cotton stalk diameter at $6.5 \%$, for $2.5 \mathrm{~mm}$ diameter lawn stems in bundles of four stems. Decreasing cutting forces at higher moisture contents were due to visibility of the stalk tissues of plant stems.

Imbabi (1992) found that the energy requirements for cutting the sesame plants ranged from $4.32-27.03$ Joule/stem according to the moisture content of stems, while the cutting force ranged from 432.14 - 1351.31 N/stem according to the moisture content of stems. El-Sheikha and ElBeba (2006) reported that the Egyptian farmers care to obtain small pieces of wheat straw or tenderized flacks (Tibn). Traditional cutting machines and local existent threshers are given them satisfaction descriptions of tenderized flacks of wheat straw (best Tibn specifications). Because of combines and reapers cause more straw losses, farmer tends to cut or mow wheat stems in a step then using local thresher and winnowing machine in another step to have good Tibn. Best specification of tenderizing flacks at $80 \%$ of straw fewer than $2.5 \mathrm{~cm}$ mixed by $18 \%$ under $5 \mathrm{~cm}$ lengths. Badr (2005), compared the performance of three different combines in terms of harvesting time, grain 
losses, fuel consumption, energy required and total cost. He found that the highest field capacity of $3.02 \mathrm{fed} / \mathrm{h}$ and the lowest field efficiency of 70.5 $\%$ were obtained at forward speed about $4.0 \mathrm{~km} / \mathrm{h}$ and grain moisture content of $22 \%$. Also, the highest fuel consumption of $18.25 \mathrm{l} / \mathrm{fed}$ and the highest energy required of $50.55 \mathrm{~kW} . \mathrm{h} /$ fed were obtained at forward speed about $1.0 \mathrm{~km} / \mathrm{h}$ and grain moisture content of $22 \%$. M oussa (2008) showed that pre-harvesting losses for Sakha 93 was about $0.51 \%$. The highest total grain losses for combine 1, 2, 3 and mower were 10.36, 7.19. 3.14 and $3.98 \%$ respectively at field speed $3.9 \mathrm{~km} / \mathrm{h}$ and grain moisture content $12.1 \%$. Besides, the highest sickle loss is $2.01 \%$ at moisture content $12.1 \%$. The highest un-threshing losses were 1.13 and $1.22 \%$ for thresher 1 and 2 respectively at grain moisture content $16.58 \%$. The highest grain damage were 2.24 and $2.02 \%$ at grain moisture content 12.1 $\%$ for thresher 1 and 2 respectively. Harvesting speed $2.7 \mathrm{~km} / \mathrm{h}$ gave the lowest energy with combine 1, 2 and 3, which were $38.95,34.76$ and $43.61 \mathrm{~kW} . \mathrm{h} / \mathrm{fed}$ respectively. Mechanical method (mower then thresher) consumed about double energy consumed by combine; while, traditional method (sickle then thresher) consume about the same energy with combine. Thresher 2 consumed less energy than thresher 1 that because thresher 2 has free knives on the drum depend on the impact. The highest criterion cost with combine 1, 2, 3 and mower are 355.9, 277.59, 177.56 and $158.06 \mathrm{LE} / \mathrm{fed}$ respectively at field speed $3.9 \mathrm{~km} / \mathrm{h}$, and grain moisture content $12.1 \%$. I smail and Abdel-M ageed (2010) stated that optimum harvesting operations as well as good systems is needed to minimize the cost and obtain maximum profits. The required of the labour number for three systems under studies were 5; 2; 15 and 23 labour per harvesting systems for combine with tank, combine with bagger, "reaper + thresher" and "manual + thresher" systems respectively. Also, the total manual energy required "kW.h/ton" recorded $0.8 \mathrm{~kW} . \mathrm{h} / \mathrm{fed}$ while; it was about $6.73 \mathrm{~kW} . \mathrm{h} / \mathrm{fed}$ for the manual system.

The investigation concerned with labors and losses which represent the most and familiar problems face the Egyptian farmers specially at harvesting periods. Japanese combines are available and usually used under Egyptian conditions widely in Egypt. This trial is to use it only in wheat reaping which is considered the most difficult step. Many options 
can be applied by changing simple procedure of back combine body, its header and conveyers to reduce reaping losses. Using the combine in two season gives high economic value in condition of many considerations.

\section{MATERIALS AND METHODS}

A field trial was carried out at Al-Srew Agri. Res. Station, Damietta Governorate, Egypt at wheat harvesting season to determine and estimate the factors and conditions affecting using Japanese type combines for wheat reaping only without proceeding threshing, winnowing and cleaning and also, maximizing using Japanese type combines in wheat reaping in addition to rice harvesting.

The combine type characteristics are shown in table. 1.

\section{Table 1: The combine characteristics:}

\begin{tabular}{||l|l|l|l||}
\hline \multicolumn{1}{|c|}{ Item } & \multicolumn{1}{|c|}{ Characteristics } & \multicolumn{1}{c||}{ Item } & Characteristics \\
\hline Engine type, model, & Kubota, Pro 481 & Height & $1920 \mathrm{~mm}$ \\
Engine power, & $48 \mathrm{hp}$ & Weight & $2015 \mathrm{~kg}$ \\
Combine dimensions: & & Cutter length, & $150 \mathrm{~cm}$ \\
Length & $4155 \mathrm{~mm}$ & Affective cutter & $140 \mathrm{~cm}$ \\
Width & $1750 \mathrm{~mm}$ & Engine speed, max & $2700 \mathrm{rpm}$ \\
\hline
\end{tabular}

A scope of the study:

Firstly,

1- Removing threshing, winnowing and cleaning components (Fig. 1).

2- Heightening the pick-up shaft 10, 15, 20 and $25 \mathrm{~cm}$ above the standardized position (original position) on the upper end header in order to prohibit wheat stems congestion and consequently reducing the effect of impact action on wheat spikelet (Fig. 2).

3- The center gravity was pinpointed before and after removing the previous components in a remote trial before treatments. These three states were fixed and primarily experimented.

\section{Secondly:}

4- Assembling four repel arms (Fig. 3), two in each side, above steering arm that move as a one unit upwards and downwards likely the steering arm motion. These four repels had a curved shape and narrower from the inlet and wider at the outlet. This objected combine turn clockwise during reaping which allowed wheat stems to fall down aside as thin layer to attain stems moisture content reduction before threshing. 
5- Installing a steel mat (Fig. 4) instead of the removed threshing components. Stems motion controlled by chain conveyers to the end of combine. A back base load was fixed to pile stems behind the combine.

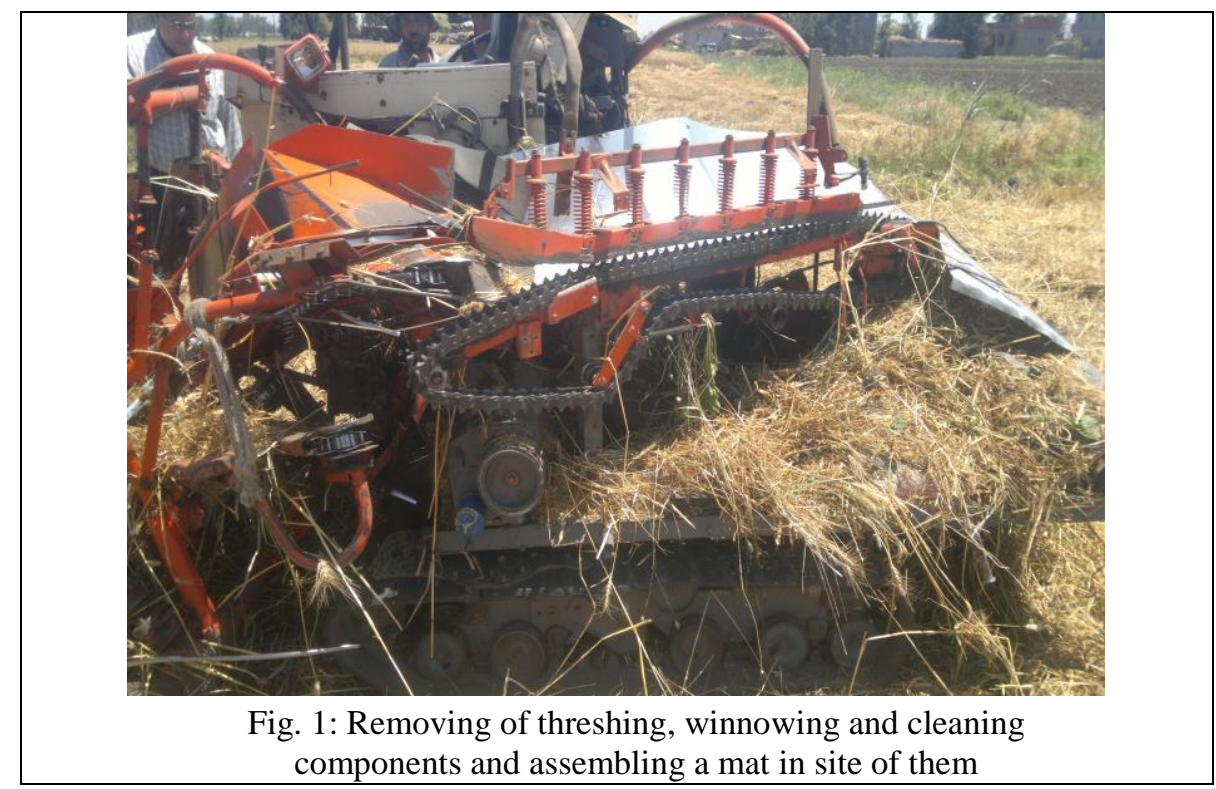

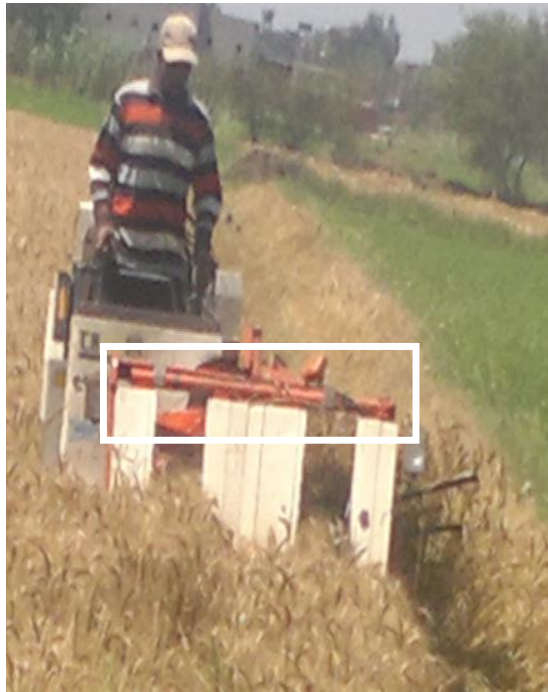

before

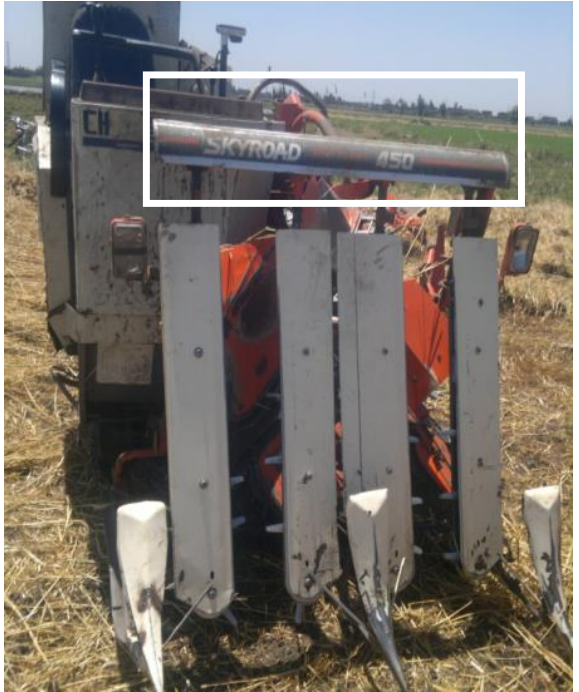

after

Fig. 2: Heightening the pick-up shaft 


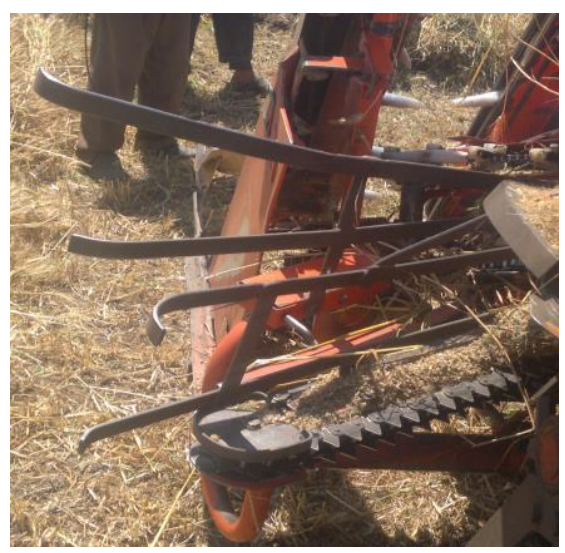

Fig. 3: Assembling repel arms on steering arm

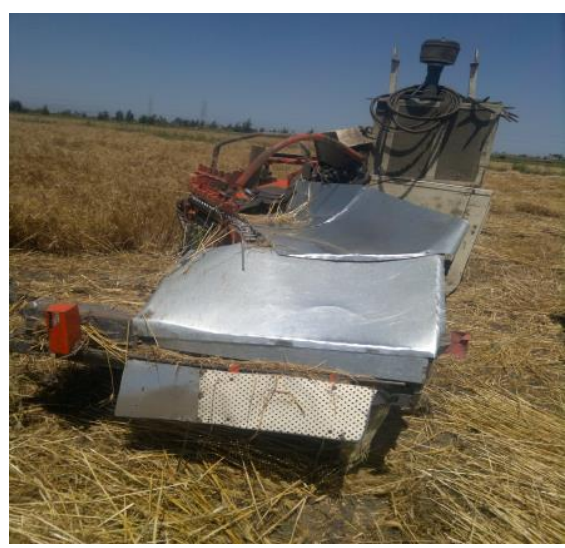

Fig. 4: Assembling a mat, under conveyer and a rear pile base

\section{The experimental procedure:}

All parts of unit were assembled and adjusted for operating suitable phase as one experiment for every state to treatments are lasted. Trials were carried out before reaching wheat moisture contents to $13.7 \%$ (d.b) as reported by El-Sheikha and El-Beba (2006).

\section{Instrumentation}

Stopwatch, measuring tape and digital balances were used for measuring time consumed, calculating forward speeds and reaped area with field capacity and weighting samples for estimating total losses.

\section{- Test factors}

- Forward speed: Reaper forward speed of 1.25, 1.8, 2.4, 3.0 and 3.6 $\mathrm{km} / \mathrm{h}$ were tested under different conditions.

- Claws speed: Speed of claws (feeding fingers) of 25, 33, 42 and 55 $\mathrm{rev} / \mathrm{min}$. was tested according to the transmission system.

- Pile base head: The head between pile base and the ground (height of the pile load base to land surface) of $40,50,65$ and $80 \mathrm{~cm}$ were examined under different forward and claws speeds.

\section{- Measurements:}

\section{1- The percentage of grain losses $(L, \%)$.}

Concluding shattering, head convoying, mat convoying and fallen by pile or rejected arms, it was determined by collecting grains lost of $10 \mathrm{~m}$ length for every travel distance at three replicates of reaper then measured the ratio to its product in weight in $\mathrm{kg}$. 


$$
\text { Grain Losses (\%) }=\frac{\text { weight of the lossed grain }}{\text { total weight }}(, \%) \ldots(1)
$$

2- Actual field capacity: Actual field capacity was the actual average time consumed during mowing operation (lost time + productive time). It can be determined from the following equation:

$$
F_{\text {Cact }}==\frac{60}{\mathrm{Tu}+\mathrm{Ti}}, \text { fed } / h
$$

Where:

$F_{\text {Cact }}=$ Actual field capacity of the topping unit.

$T u=$ Utilization time per feddan in minutes.

$T i=$ Summation of lost time per feddan in minutes.

\section{- Field efficiency:}

Field efficiency is calculated by using the values of the theoretical field capacity and effective field capacity rates as

$$
\eta=\frac{\text { actual field capacity }}{\text { theoritical field capacity }}, 100
$$

Where:

$\eta=$ Field efficiency, $\%$.

\section{1- Cutting efficiency:}

Cutting efficiency was calculated by using the following formula.

$\boldsymbol{E} \boldsymbol{c}=\frac{\mathrm{A}-\mathrm{B}}{\mathrm{A}}, 100$

Where

A : height of wheat stems above the soil service before cutting, in $\mathrm{cm}$.

$\mathrm{B}$ : height of wheat stems above the soil after cutting, $\mathrm{cm}$.

4- Fuel consumption and power needed (litre): were estimated by refilling the engine tank with a standard flask for the first and second experiments. The following formula was used to estimate power consumption by the mechanized system according to Hunt (1983), as follows:

$$
\operatorname{Power}(k W)=\frac{M_{f} * \rho_{f} * L C V * \eta_{t h} * \eta_{m e c} * 427}{3600 * 75 * 1.36}
$$

$M_{f}=$ fuel consumption, $\mathrm{L} / \mathrm{h}$,

$\rho_{f}=$ density of fuel, $\mathrm{Kg} / \mathrm{L}$ (For diesel = 0.85); 
$L C V=$ calorific value of fuel $(10000 \mathrm{kcal} / \mathrm{kg})$;

$427=$ thermo-mechanical equivalent, $\mathrm{J} / \mathrm{kcal}$,

$\eta_{t h}=$ thermal efficiency of engine $(\approx 35 \%$ for diesel engines $)$,

$\eta_{\text {mec }}=$ mechanical efficiency of engine $(\approx 80 \%)$.

While, the energy required was estimated using the following equation:

Energy requirements $(\mathrm{kW} . \mathrm{h} / \mathrm{fed})=\frac{\text { Power requiremen } \mathrm{t}(\mathrm{kW})}{\text { Actual field capacity }(\mathrm{fed} / \mathrm{h})}$..

5- Costs: The hourly cost for machine operation was determined using the following equation, Awady, (1983)

Hourly cost $=\mathrm{P} / \mathrm{H}(1 / \mathrm{A}+\mathrm{I} / 2+\mathrm{T}+\mathrm{R})+(0.9$ W.S.F $)+\mathrm{M} / 144$, .E./h..(7)

Where:

$\mathrm{P}=$ price of machine, L.E, $\quad \mathrm{H}=$ yearly working hours, $\mathrm{h} /$ year,

$\mathrm{A}=$ life expected of machine, year, $\mathrm{I}=$ interest rate / year,

$\mathrm{T}=$ taxes, over heads ratio, $\quad \mathrm{R}=$ repairs and maintenance ration,

$0.9=$ factor accounting for lubrication $\quad \mathrm{W}=$ power, $\mathrm{hp}$,

$\mathrm{S}=$ specific fuel consumption (L/hp.h), $\quad \mathrm{F}=$ fuel price, L.E. / L,

M/144 = monthly wage ratio, L.E,

The operating cost per feddan was determined using the following equation:

$$
\text { Operating costs }=\frac{\text { hourly }(\text { feddan })}{\text { Actual mowing area }(\text { feddan } / \mathrm{h})}
$$

Cost analysis and economic evaluation: The cost analysis was performed in two steps. The first step was to calculate the cost of the materials and the fabrication. The second step was to calculate the unit operating cost and was analyzed statistically and the significance according to the probability $(\mathrm{P}<0.05)$ was evaluated by the SPSS program.

\section{RESULTS AND DISCUSSION}

\section{1- Effect of reaper travel speed on the percentage of total grain losses.}

Fig. 5 showed the effect of reaper travel speed as $(1.25,1.8,2.4,3.0$ and $3.6 \mathrm{~km} / \mathrm{hr})$ with claw speeds of $(25,33,42$ and $55 \mathrm{rev} / \mathrm{min})$ on total losses under the two developed systems. It could be concluded that increasing reaper speed resulted in increasing total grain losses under all treatments. Increasing speed from 1.25 to $3 \mathrm{~km} / \mathrm{h}$ resulted in increasing total grain 
losses about $6.0 \%$ under $42 \mathrm{rev} / \mathrm{min}$ claw speed with both of repel arm and pile base. However, under without pile base, total losses increased by $11 \%$ under the same conditions of forward and claw speeds. This increment may be because of removing the pile base which was concerned with piling. Travel speed of 1.8 and $2.4 \mathrm{~km} / \mathrm{h}$ showed similar trend under the same conditions while travel speed of $3.6 \mathrm{~km} / \mathrm{h}$ caused scattering piles behind the reaper or scattering thin layers aside the repel arm reaper. Generally, increasing the total losses may be due to increasing the impact force, transferring and shaking actions which caused grain separating from wheat spikelet according to the increment of travel speed. Statistical analysis showed a significant effect between both travel speeds and total losses.
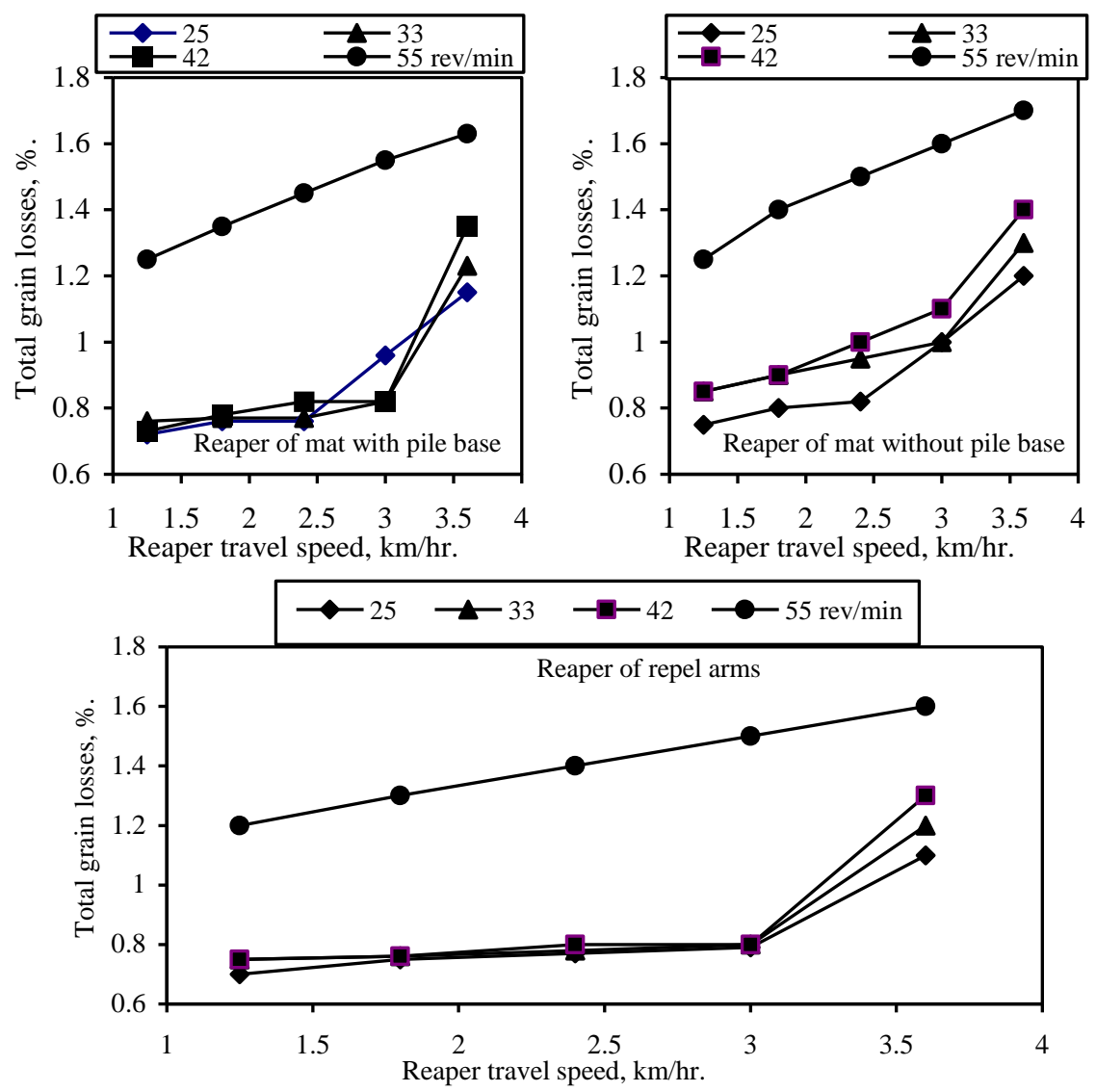

Fig. 5. Effect of reaper travel speed on the percentage of total grain losses at different claws feeding speed and pickup of $20 \mathrm{~cm}$. 


\section{2- Effect of reaper travel speed on the field efficiency.}

Figs. 6 showed the effect of reaper travel speed of $(1.25,1.8,2.4,3.0$ and $3.6 \mathrm{~km} / \mathrm{hr}$ ) with claw speed of $42 \mathrm{rev} / \mathrm{min}$ under the two developed ways on field efficiency. Data referred that increasing reaper speed resulted in increasing field efficiency. Increasing travel speed from 1.25 to $3 \mathrm{~km} / \mathrm{h}$ increased field efficiency by $20 \%$ by applied repel arm and $18 \%$ by applied pile base and without pile base. It means that field efficiency was higher with pile base followed by without pile base and the repel showed the minimum filed efficiency.
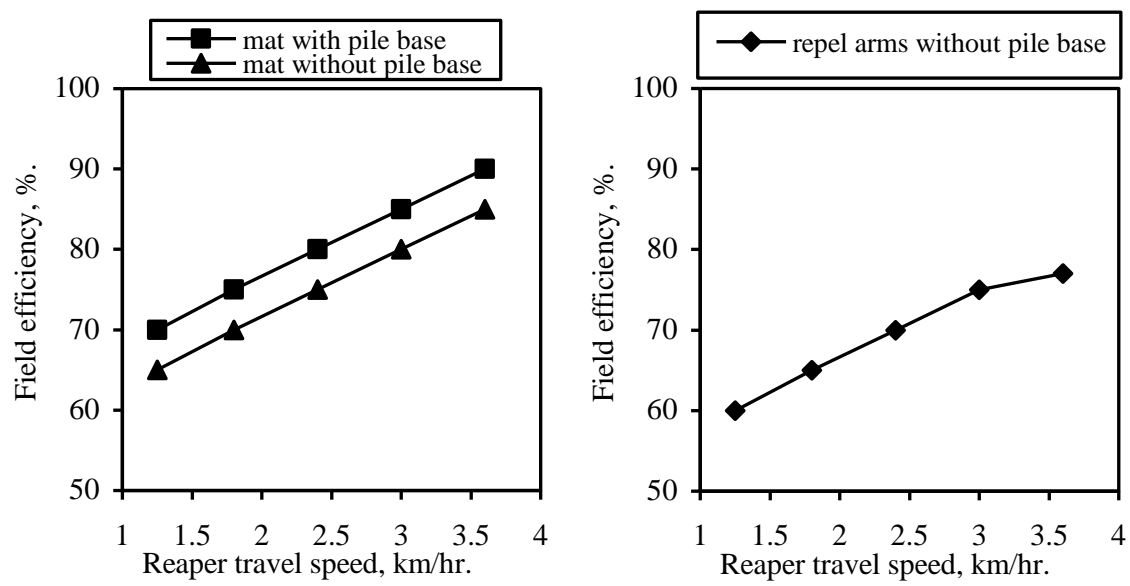

Figs. 6. Effect of reaper travel speed on the field efficiency $(\eta, \%)$ at claws feeding speed of $42 \mathrm{rev} / \mathrm{min}$ and pickup of $20 \mathrm{~cm}$.

This decrement was due to more consumed time required for operation. By assembling the pile base facilitated the reaper motion to track anticlockwise around the field which gave the obtained results. In case of repel system, the field borders must be reaped manually before reaper working as the reaped material fall aside the reaper and fall in interval drains and canals and consequently resulted in decreasing field efficiency. Data analyzed showed a significant effect of travel speed on field efficiency but showed no effect of claw speeds on field efficiency.

\section{3- Effect of claws feeding speed on the percentage of header grain losses:}

Fig. 7 showed the effect of claw speeds $(25,33,42$ and $55 \mathrm{rev} / \mathrm{min})$ in case of two developed ways of travel speed as $(1.25,1.8,2.4,3.0$ and 3.6 
$\mathrm{km} / \mathrm{hr}$ ) on header grain losses, $L$, \%. Results illustrated that increasing claw feeding speed resulted in increasing header grain losses. Increasing claw speed from 25 to $42 \mathrm{rev} / \mathrm{min}$ resulted in increasing header grain losses by $3.0 \%$ under $3 \mathrm{~km} / \mathrm{h}$ reaper travel speed, but this increment jumped to $29 \%$ by increasing claw speed from 25 to $55 \mathrm{rev} / \mathrm{min}$ with the same conditions.

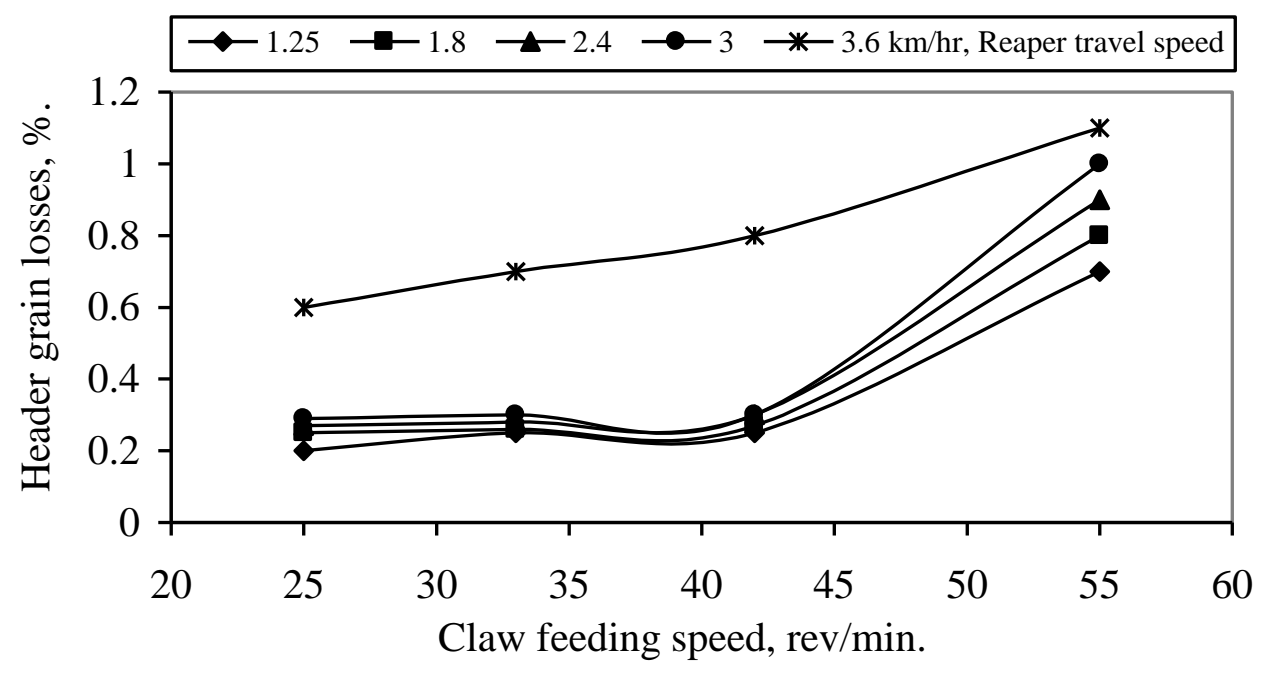

Fig. 7. Effect of claws feeding speed at different reaper travel speed on the percentage of header grain losses and pickup of $20 \mathrm{~cm}$.

All other travel speeds showed similar trend under different travel speeds and other conditions. That result could be due to increasing impact action of transferring wheat spikelet up and also vibrating or shaking action which cause grains separating from wheat spikelet. The interaction of travel speed and claws speeds showed very significant effect on header grain losses.

\section{4- Effect of heightening pickup shaft on the percentage of header grain losses:}

Fig. 8 showed the effect of pickup height $(0,5,10,15,20,25 \mathrm{~cm})$ under the two developed system with different travel speed of 1.25, 1.8, 2.4, 3.0 and $3.6 \mathrm{~km} / \mathrm{hr}$ on header grain losses, $L$, $\%$.

Results indicated that increasing pickup height decreased header grain losses. Increasing pick-up header height from 0 to $20 \mathrm{~cm}$ decreased 
header grain losses by $60 \%$ by $3 \mathrm{~km} / \mathrm{hr}$ travel speed with $42 \mathrm{rev} / \mathrm{min}$ of claw speed under all developed systems. That could be due to decreasing the impact actions between the upper claws and pickup shaft which reducing grains separating from wheat spikelet .However, the previous ratio decreased by 53.3 while increasing pick-up height to $25 \mathrm{~cm}$ under the same mentioned conditions. These results may be according to enlarging space from 20 to $25 \mathrm{~cm}$ which caused more falling of wheat stems.

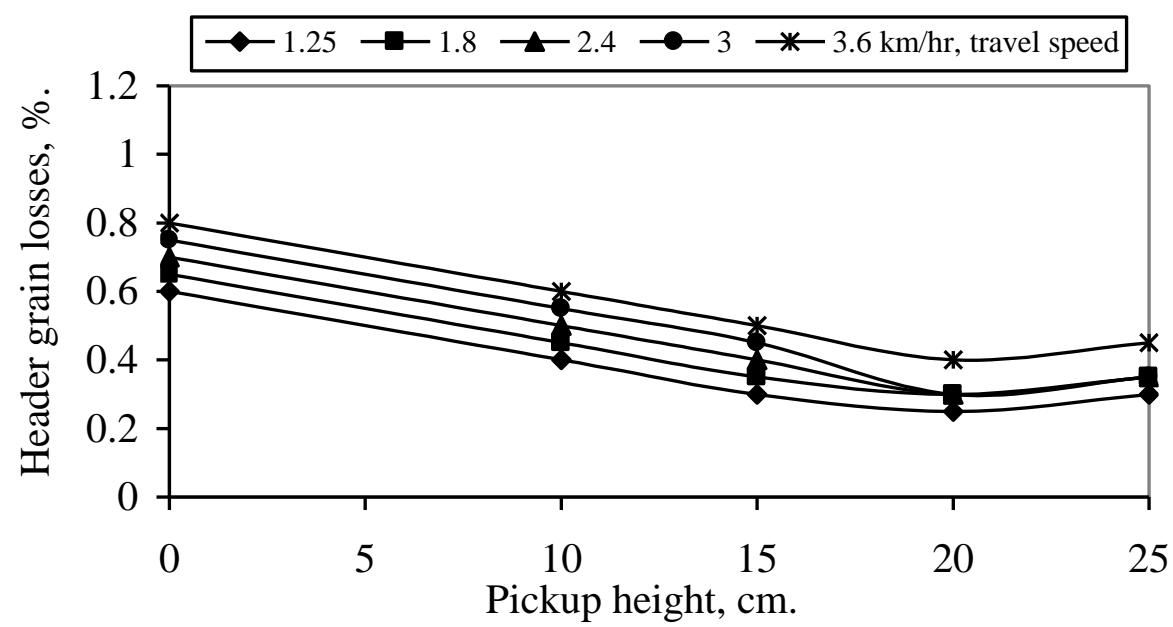

Fig. 8. Effect of pickup height at different reaper travel speed on the percentage of header grain losses

\section{5- Effect of heightening pickup shaft on the cutting efficiency:}

Fig. 9 showed the effect of reaper travel speed as $(1.25,1.8,2.4,3.0$ and $3.6 \mathrm{~km} / \mathrm{hr})$ with claw speeds of $(25,33,42$ and $55 \mathrm{rev} / \mathrm{min})$ in case of two developed ways on the cutting efficiency. Results clear that increasing heightening pickup shaft caused an increment of cutting efficiency. Increasing pickup height from 0 (original position) to $20 \mathrm{~cm}$ increasing cutting efficiency by about $6.0 \%$ with different operating condition of reaper, but increasing pickup height up than level $20 \mathrm{~cm}$ had no effect and useless for cutting efficiency. Heightening the pick-up shaft from 5 to 10 $\mathrm{cm}$ showed similar results under the different conditions. Generally, the 
original position of pick-up height showed the least value of cutting efficiency while the best value of cutting efficiency was under $20 \mathrm{~cm}$ pick-up height. That is may be due to capability for adjusting the reaper header upwards and downwards to cope with land level and in the same time avoiding impact action by upper claws with pickup shaft.

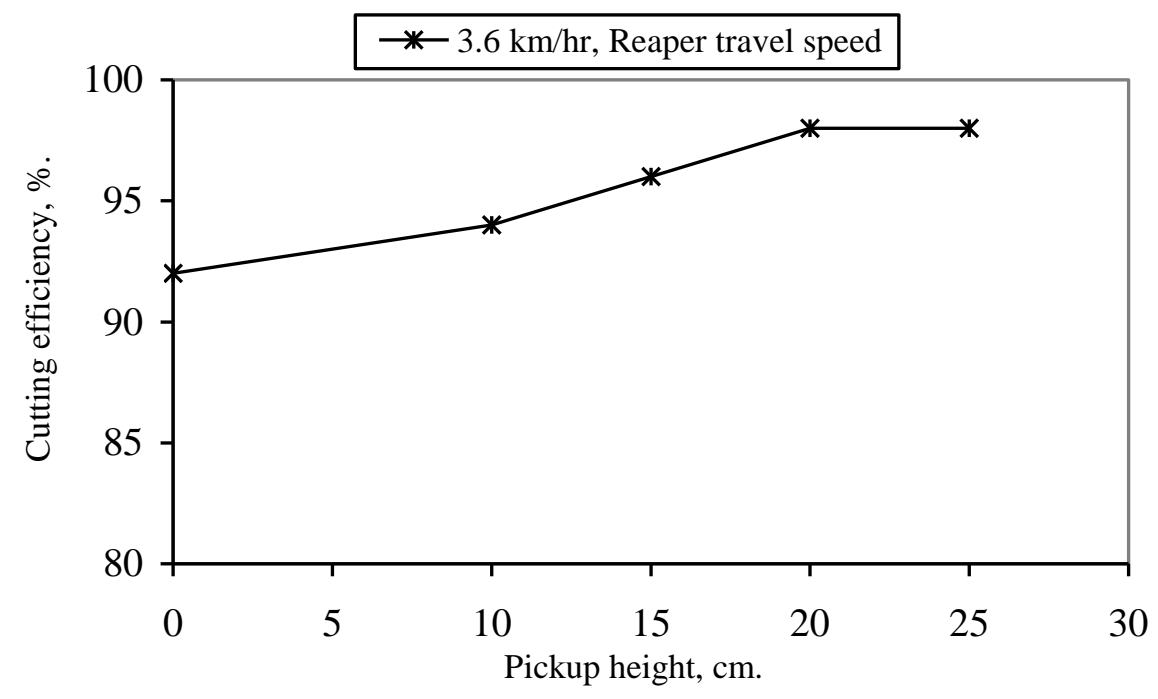

Fig. 9. Effect of pickup height at reaper travel speed of $3.6 \mathrm{~km} / \mathrm{hr}$ on the cutting efficiency

\section{6- Effect of pile base height on the percentage of grain losses.}

Fig. 10 showed the effect of pickup height $(40,50,65$ and $80 \mathrm{~cm})$ in case of two developed ways of travel speed as $(1.25,1.8,2.4,3.0$ and 3.6 $\mathrm{km} / \mathrm{hr}$ ) on header grain losses, $L$, \%. Results cleared that increasing pile base height increased grain losses. Increasing pile base height from 40 to $80 \mathrm{~cm}$ with $3 \mathrm{~km} / \mathrm{hr}$ reaper travel speed increased grain losses by about $53.6 \%$. Increasing pile base height from 40 to $50 \mathrm{~cm}$ height had no effect. Increasing height gradually from 50 to $80 \mathrm{~cm}$ losses are increased. That is could be due to increasing of impact actions as result of free fall of wheat spikelet. The maximum value of grain losses was under pile base height of $80 \mathrm{~cm}$ while the minimum value was under $50 \mathrm{~cm}$ height with travel speed of $3.6 \mathrm{~km} / \mathrm{hr}$. 


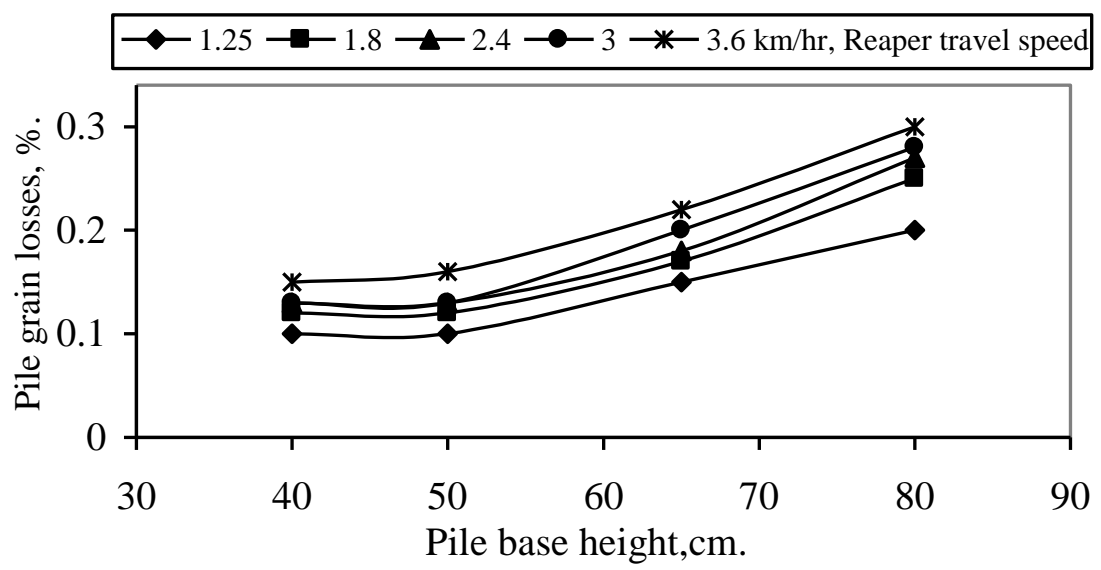

Fig 10. Effect of pile base height at different reaper travel speed on the percentage of grain losses and pickup of $20 \mathrm{~cm}$

\section{7- Power requirements at different reaper travel speed under two developed types of reaper:}

Data in Fig. 11 showed the effect of reaper travel speeds, $\mathrm{km} / \mathrm{hr}$ on the power requirements $(\mathrm{kW} / \mathrm{fed})$. Results clear that increasing reaper travel speed decreased power requirements to about $26 \%$ per unit area, that is could be due to increasing reaper field efficiency for all applied levels. According to using a conveyer with mat to transmit stems to the end of the reaper resulted in increasing power requirements by $5.8 \%$ as shown on figure 11 .

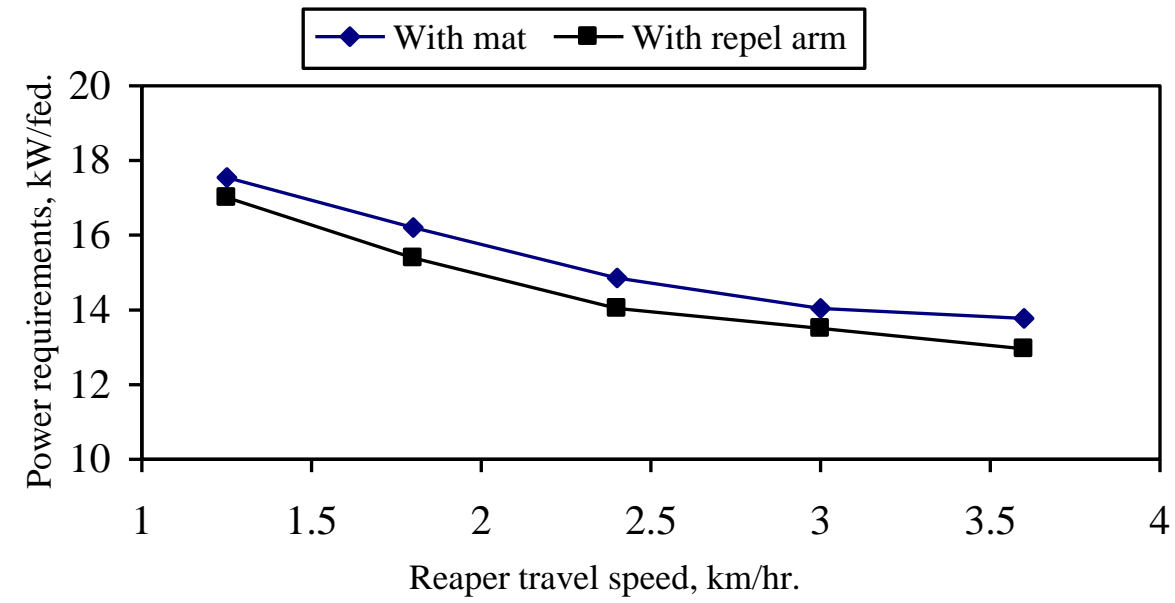

Fig 11. Power requirements at different reaper travel speed and claw speed of $42 \mathrm{rev} / \mathrm{min}$ under two developed types of reaper. 


\section{Economical studies}

The total fabrication cost of the modification in the developed unit including workshop cost was about $250 \mathrm{LE}$ at 2014 price level. The developed unit was achieved at El-Serw Agri. Res Station.

\section{CONCLUSION}

This study was carried out to develop a unit for reaping wheat by modifying the rice Japanese combine. The main results could be summarized in the following points:

- Increasing speed from 1.25 to $3 \mathrm{~km} / \mathrm{h}$ resulted in increasing total grain losses about $6.0 \%$ under $42 \mathrm{rev} / \mathrm{min}$ claw speed with both of repel arm and pile base.

- Increasing travel speed from 1.25 to $3 \mathrm{~km} / \mathrm{h}$ increased field efficiency by $20 \%$ by applied repel arm and $18 \%$ by applied pile base and without pile base.

- Increasing claw speed from 25 to $42 \mathrm{rev} / \mathrm{min}$ resulted in increasing header grain losses by $3.0 \%$ under $3 \mathrm{~km} / \mathrm{h}$ reaper travel speed, but this increment jumped to $29 \%$ by increasing claw speed from 25 to $55 \mathrm{rev} / \mathrm{min}$ with the same conditions.

- Increasing pick-up header height from zero (original position) to 20 $\mathrm{cm}$ decreased header grain losses by $60 \%$ by $3 \mathrm{~km} / \mathrm{hr}$ travel speed with $42 \mathrm{rev} / \mathrm{min}$ of claw speed under all developed systems.

- Increasing pickup height from zero (original position) to $20 \mathrm{~cm}$ increasing cutting efficiency by about $6.0 \%$ with different operating condition of reaper, but increasing pickup height up than level $20 \mathrm{~cm}$ had no effect and useless for cutting efficiency.

- Increasing pile base height gradually from 50 to $80 \mathrm{~cm}$ increased grain losses by about $53.6 \%$. 
- Power requirements decreased by $5.8 \%$ by using repel arms comparing to using a mat.

- Total costs of operating the developed unit were about $250 \mathrm{LE} /$ feddan comparing to $750 \mathrm{LE}$ for manual reaping.

\section{REFERENCES}

Awady, M. N.; E. Y. Ghoneim. And A. L .Hashish (1983 ). A critical comparison between wheat combine harvesters under Egyptian conditions. Res. Bull. No. 1920. Ain Shams Univ.; 1-13.

Badr, M. M. (2005): Comparative study between some different combine sizes in respect to unit plot area. M. Sc. Thesis. Agric. Eng. Dept., Faculty of Agric., Zagazig Univ. Egypt.

El-Beba A. Mossa and M. A El-Sheikha (2006). Development of an axial thresher. PhD. Thesis, 2006. Mansoura university.

EL-Sahar, E.A., (1988). Design of harvester appropriate for Egyptian MSe. Thesis. Fac. of Ag. Ain Shams Univ. Egypt.

Hunt, D. (1983). Farm power machinery management. Cushing. Mallay, $8^{\text {th }}$ edition: $135-137$, USA.

Imababi, A.T. (1992). Design and development of rotary harvester for harvesting sesame crop. Ph.D. Thesis Ag. Eng. Dept., Fac. of Ag., Cairo Univ. Egypt.

Ismail, Z.E. and A.E. Abdel-Mageed (2010). Workability and machinery performance for wheat harvesting. Misr J. Ag. Eng., 27 (1): $90-103$

Kepner, R.A.;R. Bainer; and E.L. Barger (1972) Principle of farm machinery. 3rd ed., Te AVI pub. Co., U.S.A: 341- 357.

M oussa, A. I. (2008). Mechanical and traditional harvesting methods for wheat crop. Misr J. Ag. Eng., 25(4): 1094-1111 


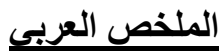

\section{تعظيم الاستفادة من كومباين الحصاد الياباني في ضم محصول القمح}

\section{أيمن موسي البيبه* يوسف يوسف رمضان* مختار قطب أحمد*}

يمثل التبن نحو ثلث القيمـة الاقتصـادية لنـاتج محصـول القمـح ، ولم ينتشـر استخدام الحاصـدات الجامعة فى حصـاد القمح فى مصر غالباً بسبب انخفاض القيمـة الغذائية للتبن النـاتج ، حيث يفقد

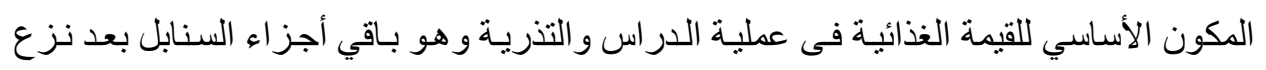

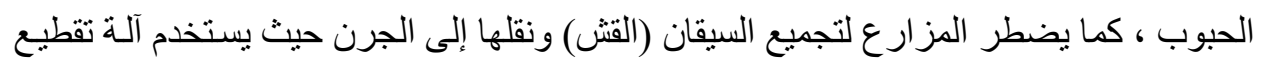

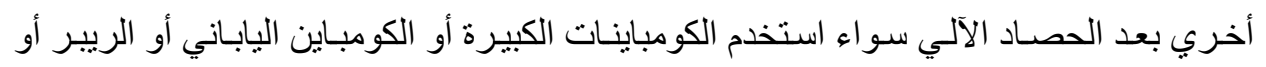

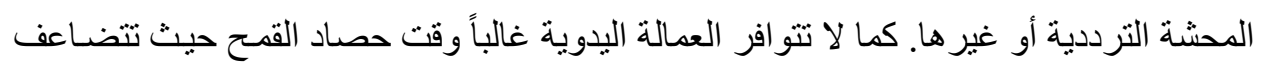
أجور ها. ورغبـة فى استحداث نظـام حصـاد يحتفظ فيـه التبن بمو اصفاته الكاملـة فقد تم تطوير كومباين الأرز الياباني المتوفر في السوق المصري واستغلاله في حصد القمح فقط (دون در اس)

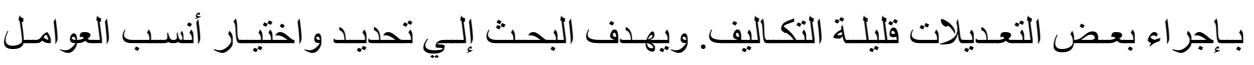
لاستخدام حاصدة الأرز الياباني في عملية حش محصول القمح مع خفض تكاليف استخدام الآلة

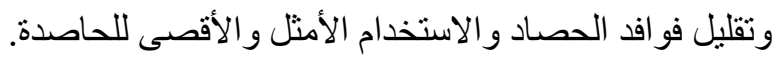

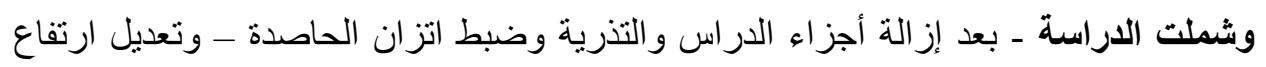

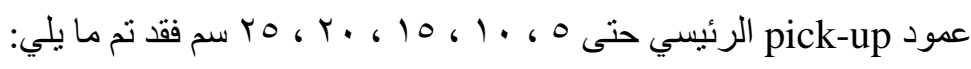
تركيب ذراع صد (repel arms) أعلى ذراع التوجيه الجانبي للحاصدة لتوجيه مسار سيقان القمح وسقوطها جانباً. تركيب حصيرة ثابتة (mat) لنقل سيقان القمح باستخدام جنزير النقل وتوجيهها للخلف ثم

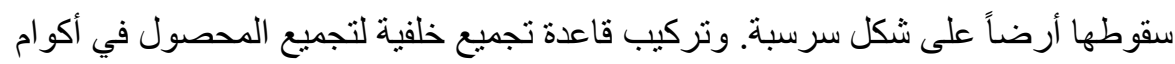
تسقط تحت تأثير وزن الكومة.

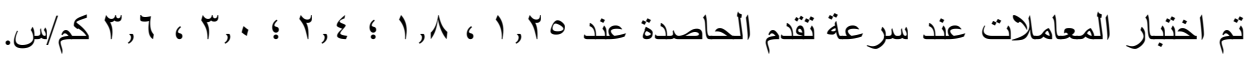

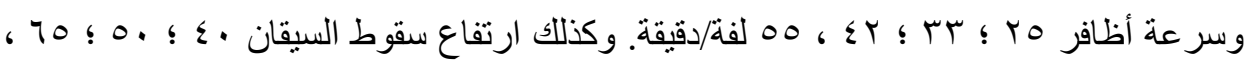
م. 1 سم.

وقد تم تقدير النسبة المئوية لفاقد الحبوب (\%). و السعة الحقلية (فدان/ساعة). وكفاءة القطع و القدرة المطلوبة (كيلوو ات/فدان) ، كما تم تقدير التكاليف الكلية بالجنيه المصري.

* معهد بحوث الهندسة الزراعية ـ مركز البحوث الزراعية ـ الاقي ـ الجيزة 
و أظهرت النتائج أن زيادة سرعة تقدم الآلة من بr ب, 1 إلى ب كم/س أدى إلى زيادة الفو اقد الكلية

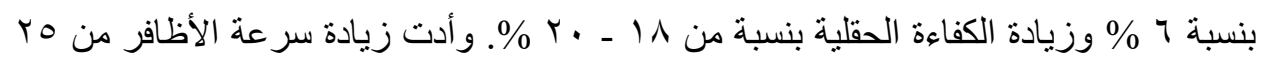

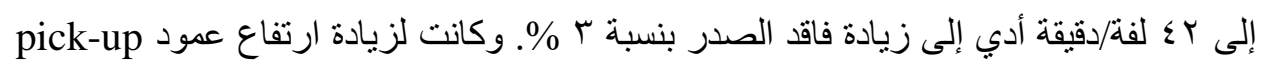

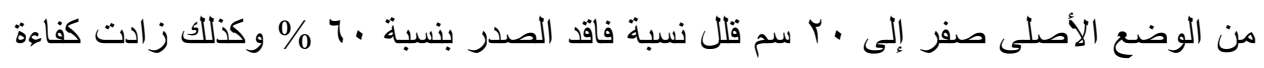

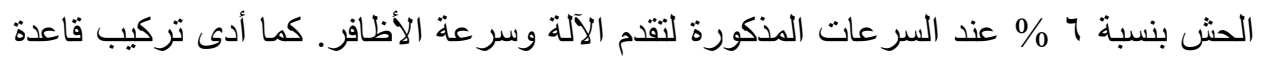

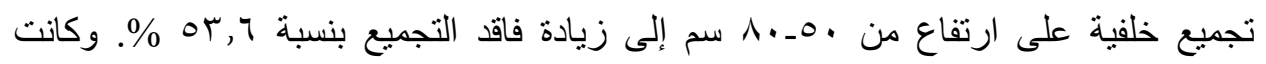

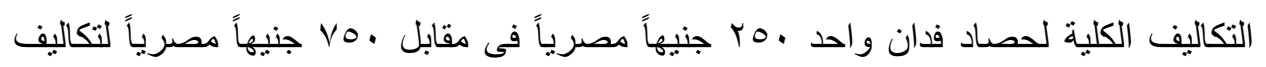

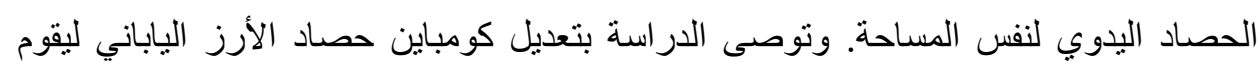

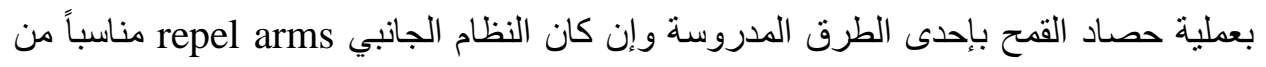
حيث انخفاض نسبة الفاقد الكلي وزيادة كفاءة الحصاد. 